\title{
Research Paper \\ Phenomenological study of the lived experience of mourning spouses during the corona virus pandemic
}

\author{
Hossein Pourshahriar ${ }^{1}$, Samin Baharshanjani ${ }^{2}$, Marziyeh Dindoost ${ }^{3}$ \\ 1. Assistant Professor, Department of Counseling, Shahid Beheshti University, Tehran, Iran. \\ 2. Ph.D Student of Psychology, Tarbiat Modares University, Tehran, Iran. \\ 3. MSc of Family counseling, Shahid Beheshti University, Tehran, Iran.
}

Citation: Pourshahriar H, Baharshanjani S, Dindoost $\mathrm{M}$. Phenomenological study of the lived experience of mourning spouses during the corona virus pandemic. J of Psychological Science. 2022; 20(107): 1931-1943.

URL: https://psychologicalscience.ir/article-1-1201-fa.html
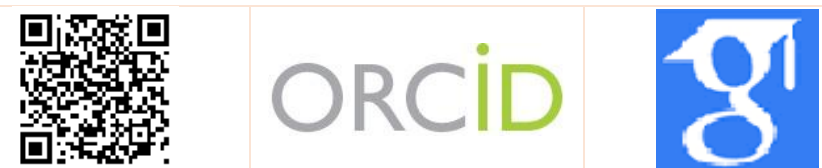

$\underline{10.52547 / J P S .20 .107 .1931}$
A R T I C L E I N F O

\section{A B S T R A C T}

Received: 31 Mar 2021 Accepted: 09 May 2021 Available: 21 Jan 2022
Background: The spread of the coronavirus causes many problems, including anxiety, depression, being away from relatives, and increasing feelings of loneliness. However, research has not yet comprehensively explained what problems and challenges will be faced by mourning spouses with coronavirus.

Aims: The aim of the present study was to identify the life experiences of mourning spouses during the corona virus pandemic.

Methods: present study was qualitative descriptive phenomenology. The sample consisted of 8 mourning spouses in Tehran who lost their partners in the period from April to September 2020. Targeted and snowball sampling methods were used. Semi-structured interviews were conducted, then implemented verbatim and analyzed by the seven-step Colaizzi's method.

Results: In this study, 4 main themes include: 1) Concerns (Worries about survival, worries about children, financial concerns); 2) personal reactions (Emotional reactions, behavioral reactions); 3) changes in social relations (Communication with relatives, communication with coworkers); 4) A change of perspective (Towards the world, towards those around) was identified.

Conclusion: According to the findings, it can be said that the lives of mourning spouses have been severely affected by this disease and the death of their spouses, and it is necessary to provide support systems for them according to their circumstances.

* Corresponding Author: Marziyeh Dindoost, MSc of Family counseling, Shahid Beheshti University, Tehran, Iran.

E-mail: m.dindoost73@yahoo.com

Tel: (+98) 918702550

2476-5740/ @ 2021 The Authors. This is an open access article under the CC BY-NC-ND license

(https://creativecommons.org/licenses/by-nc/4.0/). 


\section{Extended Abstract}

\section{Introduction}

Since late December 2019, a new phenomenon of pneumonia called coronavirus (Covid-19) has been reported in Wuhan, China, which has spread rapidly domestically and internationally and has become a pandemic (Y. Bai et al., 2020).

According to the latest global statistics of the Wordmeter database, as of October 20, 2020, $122,435,348$ people in the world have contracted the Covid-19 disease, of which 2,704,440 people lost their lives.

In the event of an outbreak of a contagious disease, quarantine is considered necessary and is one of several public health measures to prevent the spread of an outbreak (Brooks et al., 2020). Although quarantine is considered essential, the length of quarantine (Reynolds et al., 2008), separation from loved ones, loss of freedom (Barbisch, Koenig, \& Shih, 2015), uncertainty about illness (Desclaux, Badji, Ndione, \& Sow, 2017), fatigue, frustration (Cava, Fay, Beanlands, McCay, \& Wignall, 2005), and inadequate resources and information (Duan \& Zhu, 2020) are all sources of stress during quarantine. Therefore, it is considered as an unpleasant experience that will inevitably have many psychological effects during the outbreak of the disease (Rubin \& Wessely, 2020). These effects may reflect the impact of mental health on those affected (Duan \& Zhu, 2020), the impact of socioeconomic changes (Ayittey, Ayittey, Chiwero, Kamasah, \& Dzuvor, 2020), and the impact of prevention and quarantine (Rubin \& Wessely, 2020) on the general population.

Research from the American Psychological Association (2020) shows that some psychological problems, including anxiety and depression, can cause couples to separate and increase loneliness (American Psychological Association, 2020). In various crises, couples are confused, tired, and overwhelmed. They are therefore more inclined to be overly critical or argumentative, blaming their partner, offering less support, and being less satisfied with their relationship (Barton, Beach, Bryant, Lavner, \& Brody, 2018). It is important to note that the form and nature of a relationship in crises is different in a relationship where both people are healthy than when one of the spouses is ill or has lost their spouse to illness.

The nature of grief becomes more complex during an epidemic of a disease or other natural event, and the grieving spouse experiences more painful emotional trauma due to exposure to various aspects, resulting in emotional, economic, and social vulnerability (Kristensen, Weisæth, \& Heir, 2012; Li, Aida, Hikichi, Kondo, \& Kawachi, 2019).

Other problems following the death of a spouse include increased anxiety and feelings of loneliness and lack of social support, which occur during an epidemic due to social distance and the diminished presence of relatives to grieve and accompany the mourner. This increases a person's vulnerability and reduces emotional adjustment (Gamino, Easterling, Stirman, \& Sewell, 2000).

Given all of this and the specific issues faced by survivors of coronavirus disease and death of a family member, the lack of research on families suffering from coronavirus, and the need to be familiar with the specific issues faced by these individuals to provide professional services in the clinical setting, the purpose of this study is to provide an in-depth examination of surviving spouses and to answer the question of how surviving spouses experience death from coronavirus and what components affect them?

\section{Method}

The method of the present study was qualitative interpretive phenomenology, examining the experiences of grieving spouses during the coronavirus outbreak. The statistical population of the study was all married and bereaved men and women in Tehran who lost their spouses between April and September 2019. Purposive and snowball methods were used for sampling. In this way, 8 spouses were selected who were grieving because of this disease. The average age of the participants was 43.5 years. The demographic data of the participants are shown in Table 1. Inclusion criteria were that the death of the spouse occurred during the coronavirus epidemic due to the disease, the duration of the marriage was at least one year, the participants had the necessary skills to read and write and express their personal 
experiences and participate in the research with their satisfaction. After collecting demographic data, interview questions were asked in a semi-structured manner. In this method, the number of subjects has reached quorum when the responses reach a state of multiplicity and saturation. In this study, this saturation was reached with 8 subjects for grieving spouses. The average interview time was 45 minutes and was conducted by telephone.

Colaizzi's (1969) method was used to analyze the data. Finally, to validate the results, participants were asked to compare the findings with their own experiences to ensure that the researchers understood the experiments correctly.

\section{Measures}

Checklist of demographic characteristics: This questionnaire contained information such as age, age of spouse, duration of spouse's death, number of children, occupation and education, and occupation and education of spouse.

Semi-structured in-depth interviews: In this study, women and men who lost their spouses to coronavirus disease were interviewed. The interview questions were asked by the researcher according to the purpose of the study and to identify the experiences of this group of spouses and under the supervision and approval of the supervisor. The first question was: how do you experience grief due to coronavirus? Other questions were: What new problems has the death of your spouse created for you? What changes have occurred in your family life? Depending on the participants' answers, the next questions were then asked. In qualitative research, the criterion of reliability is used to measure the validity and reliability of the instrument. The reliability of the instrument can be measured by 4 components. These criteria were considered in the present study.

\section{Results}

In this study, 4 major themes were extracted from the responses of grieving spouses. These themes included subthemes.

1) The first theme: Concerns

The first theme was concerns related to the coronavirus outbreak. These themes can be divided into three subcategories: Worries about survival, worries about children, and financial concerns.
Worries about survival: Most surviving spouses in this study reported that since they lost a family member to coronavirus disease, they were not fearful of contracting the disease but expressed concern about survival after their spouse's death. Being a burden on others, society's view of widows, ambivalence about remarriage in the future, loneliness in old age, and feeling unable to bear problems alone were concepts gleaned from the conversations of this group of spouses. For example; Code 1: I do not want my son-in-law to think that I am going to be their burden from now on. Code 7: We had a very emotional life together and I feel like I can no longer continue without my wife. Code 4: My mother says you can still get married now.

Worries about children: the child's psychological problems, poor educational attainment, the child's dependence on the deceased parent, child marriage, and single parenthood were some of the issues that emerged from this group of spouses' discussions. For example; code 2: Our house is filled with sadness, my daughter is also a teenager, she is very upset, and has gotten depressed and aggressive. Code 7: The child was very dependent on her mother, what should I do now? Code 3: I do not know how to raise these children alone in this situation.

Financial concerns: being a single parent, the worries of these surviving spouses concerned the management of financial resources, losing part of their source of income which forced them to use their life savings, the difficulty of providing for living and medical expenses, and the difficulty of finding a new job. For example; Code 6: My husband worked in someone else's shop, so now we have no income and I have to do something myself. Code 5: My wife helped us with expenses, now that amount has been cut and I have to work twice as much. Code 1: I do not know how I am going to cover the income and the expenses of the house since all this was in the hands of my husband.

2) The second theme: personal reactions

The second theme was the personal reactions of individuals at the time of the spread of coronavirus and was divided into two subcategories: Behavioral Reactions and emotional reactions. 
Behavioral reactions: The mourners described reactions such as resisting funerals, hiding the cause of death from those around them, taking health principles more seriously, being extremely caring of children to avoid them getting sick, and trying to reassure their children and keep the family together. for example; Code 3: Well, I insisted on not holding a funeral; I did not want people to say that they got the Coronavirus because they were there. Code 1: We did not tell anyone that my wife died of corona because she had been in the hospital for a long time. Code 4: Since my child no longer had a father, I pulled myself together to take care of her. Emotional reactions: Feeling sad and depressed, the tendency to get sick and then die, the feeling that life has been destroyed, the feeling of helplessness, compassion for the deceased spouse, these were some of the concepts seen in the speeches of the grieving spouses. For example: code 5: I feel like the whole life we built together was destroyed after my wife died. Code 6: My spouse was my support, now I have no support or protection. Code 6: There is still sadness in our home.

3) The third theme: changes in social relations

The third major theme was the changes in social relationships that occurred after the outbreak of coronavirus and the death of a spouse. These changes were divided into two categories: Relationship with Relatives and Relationship with Work Colleagues.

Relation with relatives: In their relationship with relatives, grieving spouses experienced many negative consequences. Terms such as extreme reactions, distant relatives, feelings of rejection, feelings of stigmatization, and declining relationships were some of the themes they mentioned. Example: code 2: The night my spouse died I was all alone, no one came forward, everyone was scared and ran away from me. Code 3: It was like it was my fault my spouse died from the Corona. Even after a few weeks, everyone kept staying away from me. Code 6: When I went to someone's house, they were so angry and scared that I had to go back myself.

Relation to colleagues: In relation to work colleagues, the stigma of illness was one of the cases cited by the surviving spouse. Following the death of their spouse, communication with colleagues also decreased. For example; code 7: No one approached me at work. Code 1: Some of the people we used to think were enlightened colleagues disappeared altogether, for example.

4) The fourth main theme: change of perspective

The fourth and final theme identified was change of perspective and is divided into two subthemes: Change of perspective on the world and on the people around us.

Changed worldview: instability of the world, change in the meaning of life, sense of impending death, decrease in life expectancy, and sometimes hope in the remaining years of life were some of the changes that occurred in these individuals. For example: code 2: I think I'm also going to die. Code 3: I have seen how worthless and impermanent the world can take my wife away from me in 10 days. Code 8: I do not have the patience to go on living, I force myself until I die. Code 1: I hope to improve my situation and the situation of the world.

Change of perspective on the people around: Getting to know more about the relatives and friends, distinguishing friend from foe, and being pessimistic about medical personnel were some of the concepts mentioned by grieving spouses about their changed perspective. For example: code 4: During this illness I have found out who really wants me and who is only pretending. Code 7: I have realized my place in the family and how much I value them. Code 1: I was under pressure for 50 hard days from nurses and doctors who demoralized me and treated me badly.

Table 1. Demographic characteristics of the participants

\begin{tabular}{|c|c|c|c|c|c|c|c|c|c|}
\hline participant & Gender & Age & Spouse age & $\begin{array}{c}\text { Duration of } \\
\text { spouse's death }\end{array}$ & $\begin{array}{c}\text { Number of } \\
\text { children }\end{array}$ & Job & Education & Spouse job & $\begin{array}{c}\text { Spouse } \\
\text { education }\end{array}$ \\
\hline Code 1 & Female & 56 & 60 & 1 month & 4 & Housewife & $\begin{array}{l}\text { High } \\
\text { school }\end{array}$ & Freelance & High school \\
\hline Code 2 & Female & 36 & 42 & 3 months & 1 & Teacher & bachelor's & Nurse & Bachelor's \\
\hline Code 3 & Male & 47 & 51 & 5 months & 2 & Employee & $\begin{array}{l}\text { Associate } \\
\text { Degree }\end{array}$ & Employee & $\begin{array}{l}\text { Associate } \\
\text { Degree }\end{array}$ \\
\hline Code 4 & Female & 32 & 43 & 4.5 months & 1 & Housewife & Bachelor's & Freelance & Bachelor's \\
\hline
\end{tabular}




\begin{tabular}{|c|c|c|c|c|c|c|c|c|c|}
\hline participant & Gender & Age & Spouse age & $\begin{array}{c}\text { Duration of } \\
\text { spouse's death }\end{array}$ & $\begin{array}{c}\text { Number of } \\
\text { children }\end{array}$ & Job & Education & Spouse job & $\begin{array}{c}\text { Spouse } \\
\text { education }\end{array}$ \\
\hline Code 5 & Male & 56 & 49 & 6 months & 2 & Specialist & P.H.D & $\begin{array}{c}\text { General } \\
\text { Practitioner }\end{array}$ & P.H.D \\
\hline Code 6 & Female & 23 & 28 & 3 months & 0 & Housewife & Bachelor's & Freelance & Diploma \\
\hline Code 7 & Male & 44 & 44 & 5 months & 1 & Teacher & Masters & Housewife & Bachelor's \\
\hline Code 8 & Male & 52 & 52 & 4.5 months & 2 & Freelance & Diploma & Housewife & High school \\
\hline
\end{tabular}

\section{Conclusion}

The purpose of this study was to accurately determine the life experiences of bereaved spouses who have lost their spouse to corona disease. The research data suggest that these individuals are affected by concerns raised by the outbreak or death of their spouse, their own personal reactions, changes in social relationships, and changes in attitudes regarding the.

The first theme to emerge was the concerns of this group of spouses, expressed in terms of worries about survival, worries about children, and financial concerns. Men and women who lose their spouse feel a deep pain that may be different from other deaths (Hardy, Concato, \& Gill, 2004). For they had a common life together with children, income, intimacy, and a shared identity (Haase \& Johnston, 2012). The death of a spouse, especially if the children are still dependent on him or her, disrupts the dynamic within the family and can expose the survivors to physical and psychological problems.

Regarding the worries about children, research shows that limitations in social interaction can lead to anxiety and depression in people (Sood, 2020), and these problems were among the concerns parents in the present study expressed about their children.

Financial worries are another aspect of the worries mentioned in this study and other similar studies. Covid-19 has dealt a severe blow to the economies of the countries and has led to financial insecurity and the resulting stress for the people (Mohanty, 2020).

The second theme of the study was the personal reactions that grieving spouses exhibited depending on their situation. Participants described these reactions as physical reactions and emotional reactions.

Regarding physical health and behavioral responses, participants in the present study referred to physical care for themselves and their family members. This is because people in critical situations, such as the onset of such diseases, are very concerned about the situation of their family and seek intensive and continuous care for them (Caleo et al., 2018). In addition to their efforts to protect the health of other family members, bereaved spouses also behaved secretively regarding the health of the missing spouse.

The third theme relates to the changes that took place in the social relationships of the research participants. These changes were examined about relatives, loved ones, and colleagues. Since the coronavirus crisis affected people in their most important, committed, and intimate relationships (Stanley \& Markman, 2020), this also applies to relationships with others, such as relatives and colleagues.

The last theme extracted was the change in perspective mentioned by the surviving spouses. Changes in attitude towards the world and the people around them were inferred from what people said. Although coronavirus disease has affected people's health and well-being, damaged the economies of many countries, and led to uncertainty about the future, it may also have had positive effects on people's motivation to protect their relationships (Stanley \& Markman, 2020). Musapur, Changi ashtiyani and Kahrobaei kalkhuran alya (2020) also noted that despite all the suffering and pain caused by this epidemic, it has made people think more about the existential meaning and related concepts such as death and has led to the development of beliefs for them.

Attitudes toward those around the grieving spouses also changed. During the onset of an illness, the vulnerability of families increases, and culture plays an important role in the expression of emotions and needs, especially after the death of a spouse (Walsh, 2020). On the other hand, the particular conditions of this illness place great emphasis on maintaining physical and social distance between people, and the combination of these factors is likely to reduce the 
expression of emotions in grieving spouses and lead to a change in their perspective toward others.

What matters is that the grieving spouses need support during this time, and if that support cannot be provided physically and in person, it must be provided in other ways.

One of the limitations of this study is that due to the location of the researchers and the individuals studied, and due to the prevalence of coronavirus, telephone interviews were conducted, which may result in the loss of some nonverbal data. In addition, given the number of samples studied, caution should be exercised in generalizing the results. It is suggested that we also examine the lived experiences of children and parents. In this case, we can compare the lived experiences of a phenomenon from the perspective of all members of a family. The results of the present study may be useful for designing educational packages to empower grieving spouses of Covid-19 disease and may be used by patient support centers, hospitals, and grieving families. It can also be used for cultural studies examining the disease and its impact on the cultures of different countries.

\section{Ethical Considerations}

Compliance with ethical guidelines: Before participating in the study, all participants were informed that they were taking part in a research project and were assured that their identity was unknown. They were fully informed of the principle of research and interview confidentiality and agreed to participate in the study. Participants were also assured that they could withdraw from the study at any time if they wished to end their participation and that they would be informed of the results if they wished to do so.

Funding: This study did not receive any funding from government, private or non-profit organizations.

Authors' contribution: Dr. Hossein Pourshahriar: preparation of the introduction and method of the article.

Samin BaharShanjani: conducting the qualitative interviews and preparing the discussion and the conclusion section

Marziyeh Dindoost: conducting the qualitative interviews and analyzing the research data.

Conflict of interest: There is no conflict of interest between the authors in this study.

Acknowledgments: Acknowledgement and thanks are hereby extended to all the valued participants in the study. 


\section{مطالعهُ يديدارشناختى تجربهُ زيستهُ همسران سو گوار در دوره همل كيرى ويروس كرونا}

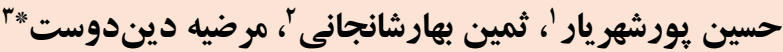

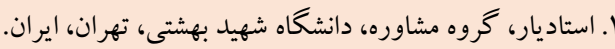

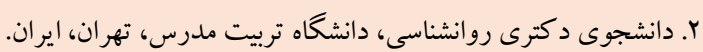

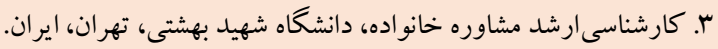

زمينه: با شيوع ويروس كرونا آسيبهاى بسيارى ازجمله اضطراب، افسردىى، دورى از خويشاوندان و افزايش حس تنهايى ايجاد مى شيود.

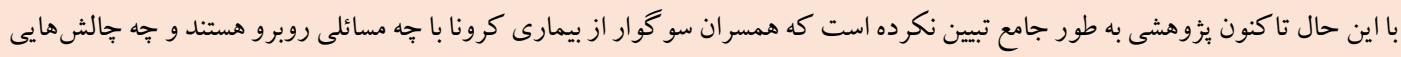
را رواهند داشت. هدف: هدف از بُزوهش حاضر شناسايى تجارب زيستة همسران سو گوار در دورة همه گيرى ويروس كرونا بود.

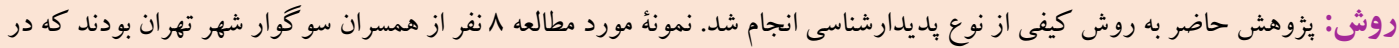

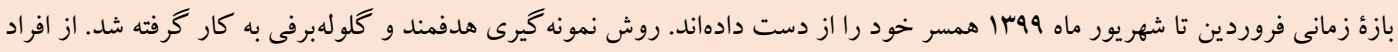

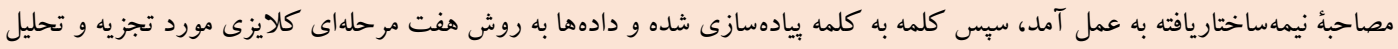
قرار گرفت.

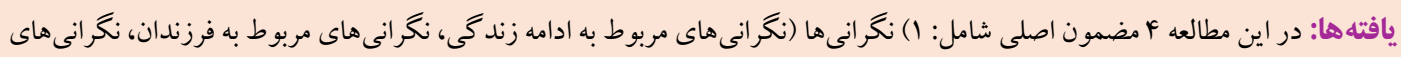
مالى)؛ r) واكنشهاى شخصى (واكنشهاى عاطفى، واكنشهاى رفتارى)؛ r) تغيير ات روابط اجتماعى (ارتباط با اقو ام، ارتباط با همكاران)؛

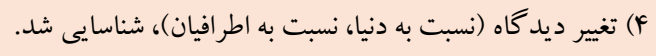

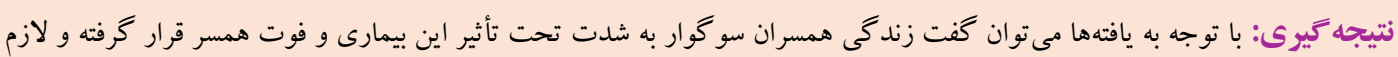


استدلال گر شوند، شريكك خود را سرزنش كنند، حمايت كمترى را ارائه دهند و رضايت كمترى از رابطهشان داشته باشند (بارتن، بيج)، براين، لاونر

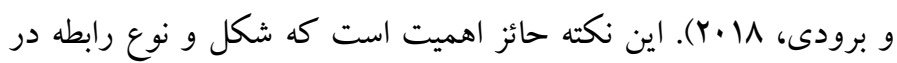

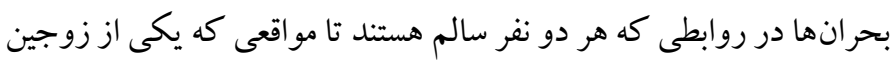

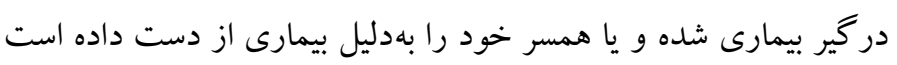
متفاوت مىباشد. ماهيت سوگت در دوران همه گيرى يك بيمارى و يا ساير وقايع طبيعى

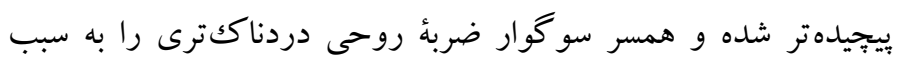
كرفتارى در ناراحتى از جوانب مختلف تجربه مى كند كه اين امر آسيب

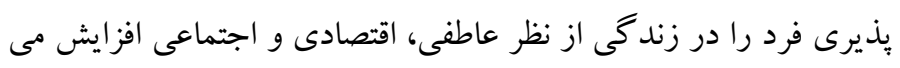

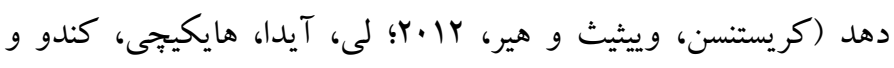

كاواجى، از ديخر مشكلات بِ از فوت همسر افزايش اضطراب و احساس تنهايى و حذف يكك موقعيت مهم حمايت اجتماعى است كه در دوران همه گيرى يكك بيمارى به سبب رعايت فاصله كذارى اجتماعى و كمرنگك شدن حضور نزديكان جهت عزادارى و همراهى با فرد سو گوار ايجاد مى شوداد.

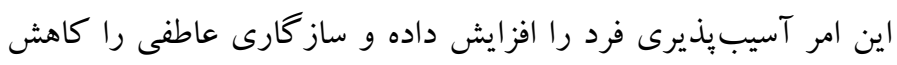

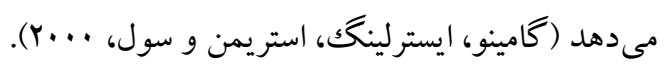

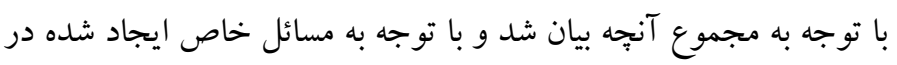

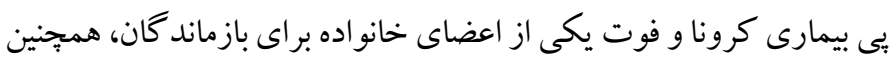
وجود يُوهشهاى اندكى درخصوص خانوادههاى سو گوار از بيمارى

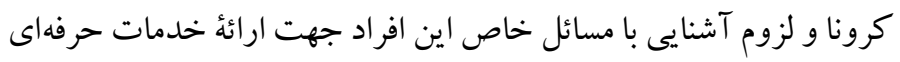
در محيطهاى بالينى، هدف از يثروهش حاضر مطالعه عميق همسران سو گوار و بِاسخ به اين سؤال است كه همسران سو گُوار از بيمارى كرونا،

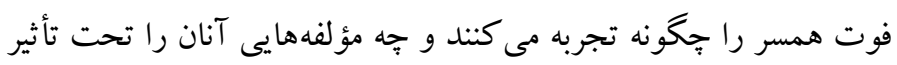

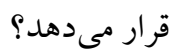

روش

الف) طرح ئوهش و شر كت كنند كان: روش يزوهش حاضر كيفى از نوع بديدارشناسى تفسيرى بود كه تجربه همسران سو گوار در دورهُ شيوع

${ }^{3}$. worldmeter
مقلدمه

از اواخر دسامبر 19 أr، يكك بديدة جديد از بيمارىهاى ذاتالريه با نام

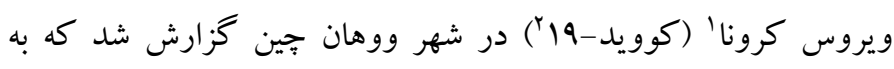
سرعت در داخل و به صورت بين المللى شيوع ييدا كرد و به يكك بيمارى همه گير تبديل شد (باى و همكاران، ·.r.Y.

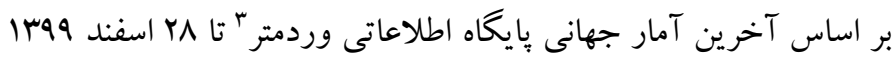

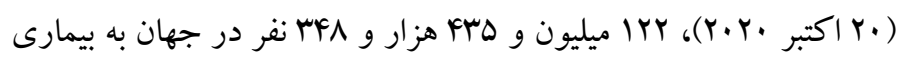

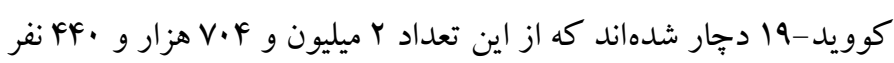
جان خود را از دست دادهاند. در هنگام شيوع بيمارىهاى واگير، قرنطينه امرى ضرورى تلقى مى شىود و

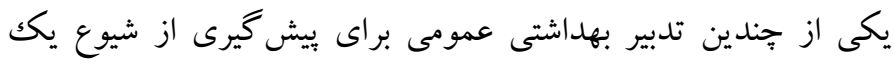

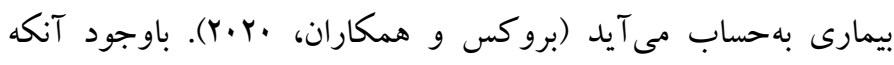

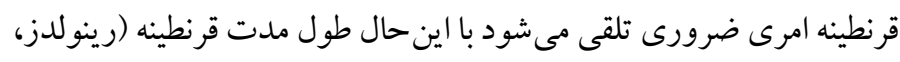

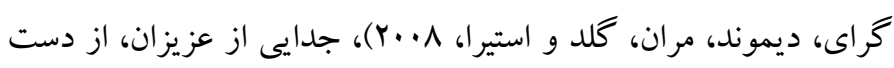

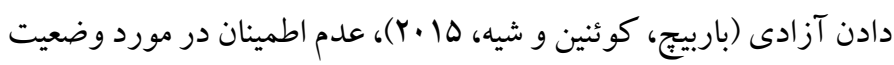

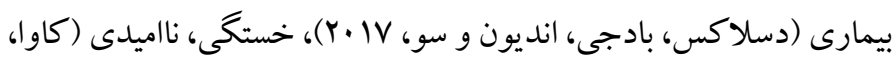

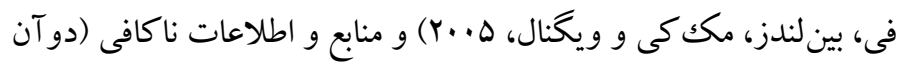

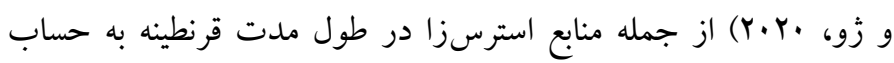

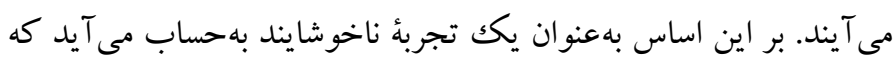

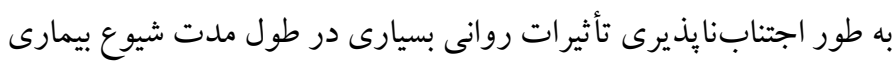

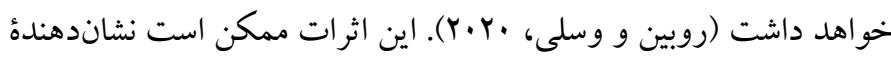

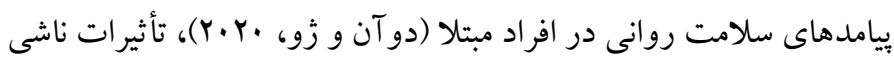

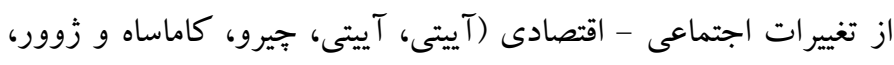

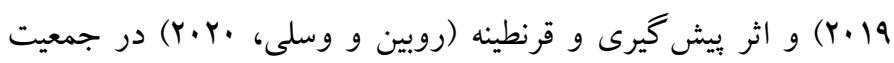

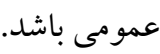

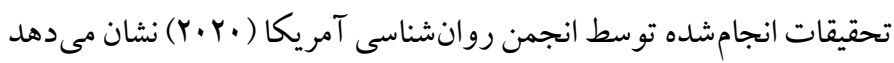

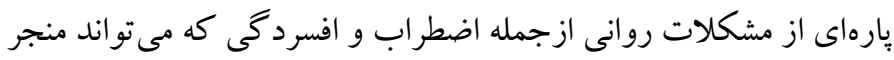
به دورى زوجين از يكديخر و بالا رفتن حس تنهايى شود از سوى آنس آنها

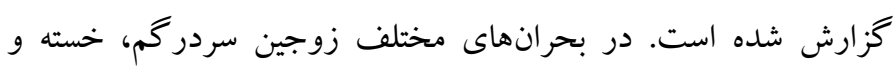
مغلوب هستند، لذا اين احتمال وجود دارد كه بيش از حد منتقد و يا

1. Corona virus

2. COVID-19 
يافته هاى حاصل را با تجربه خود مقايسه كنند تا اطمينان حاصل شود كه

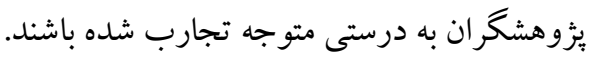

ب) ابزار

يرسشنامة ويز گى هاى جمعيت شناختى: اين برسشنامه حاوى اطلاعاتى از

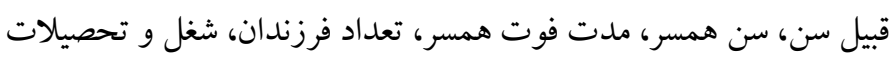

$$
\text { و شغل و تحصيلات همسر بود. }
$$

مصاحبة عميق نيمه ساختار يافته: در بيزوهش حاضر با زنان و مردانى كه

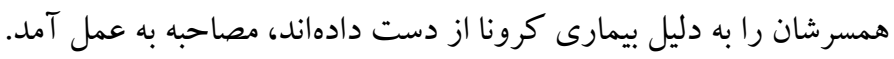
سؤالات مصاحبه با توجه به هدف يُزوهش و در راستاى شناسايى تجربهُ اين كروه از همسران توسط بثزوهشخر و با نظارت و تأييد استاد راهنما مطرح

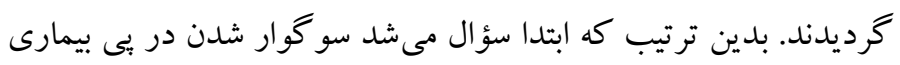
كرونا را جطور تجربه مى كنيد؟ ديخر سؤالات شامل: فوت همسر جه به مسائل

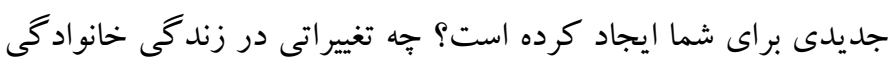
شما ايجاد شده است؟ سبس با توجه به بِاسخهاى شركت كنند كان ادامه

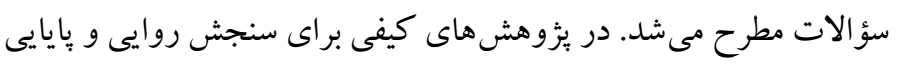

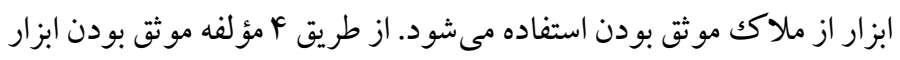
قابل سنجش است. اين ملاككها در يزوهش حاضر مورد توجه قرار گرفته
بيمارى كرونا مورد مطالعه قرار كرفت. جامعه آمارى يزوهش كلئ زنان و مردان متأهل و سو گوار شهر تهران بودند كه در بازه زمانى فروردين تا

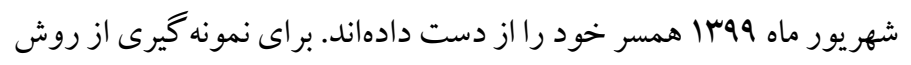
نمونه گيرى هدفمند و گلولهبرفى استفاده شد. بدين طريق ^همسر سو گوار

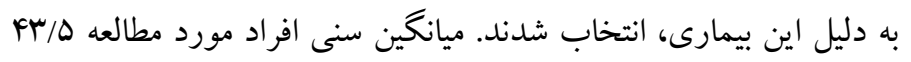
سال بود. اطلاعات دمو گرافيكك شركت كنندگان در جدول ا ارائه شده است. معيارهاى ورود به يثوهش عبارت بودند از اينكه فوت همسر در دورةٔ

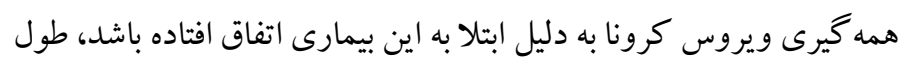
مدت ازدواج حداقل يكك سال باشد، شركت كنند گان توانايىهاى لازم خو اندن و نوشتن و بيان تجربيات شخصى خود را داشته و با رضايت خود

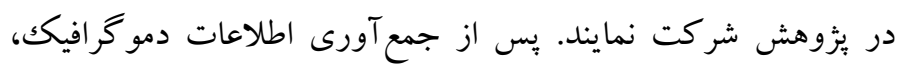
سؤالات مصاحبه به شكل نيمهساختاريافته مطرح كرديد. در اين شيوه

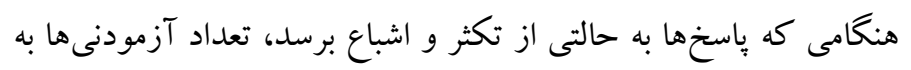
حد نصاب رسيده است كه در اين ئزوهش اين اشباع با م آزمودنى براى

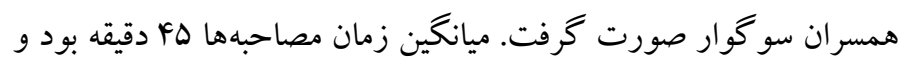
به صورت تلفنى انجام گرفت. به منظور تجزيه و تحليل دادهها از روش كلايزى (1999) استفاده شد. در

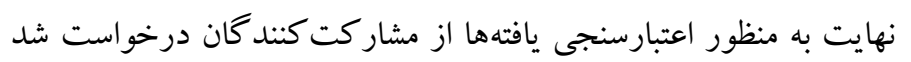

جدول ا. اطلاعات دموكر افيك شر كت كنند كان

\begin{tabular}{|c|c|c|c|c|c|c|c|c|c|}
\hline تحصيلات همسر & شغل همسر & تحصيلات & | الغل & تعداد فرزنددان & مدت زمان مركَ همسر & سن همسر & سن & جنسيت & شركت كند كان \\
\hline دبيرستان & آزاد & دبيرستان & خانه دار & f & اماه & (9 & ( ) & زن & كد 1 \\
\hline كارشناسى & ير برستار & كارشناسى & معلم & 1 & r r Tlه & ( & وبr4 سال & زن ان & كد r \\
\hline فوق دييلم & كارمند & فوق دييلم & كارمند & r & D ماه & اله سال & F & 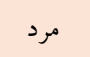 & كد \\
\hline كارشناسى & آزاد & كارشناسى & خانه دار & 1 & F/D ماه & كال سال & كrr & 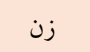 & كد r \\
\hline دكترى & يز شكك عمومى & د دكترى & يز شك متخصص & r & و 9 & & ل & مرد & كد ه \\
\hline ديبلم & آزاد & كارشناسى & خانه دار & . & r Tlo & ل ب سال & r سז سال & زن - ان & كد 4 \\
\hline كارشناسى & خانه دار & كارشناسى ارشد & معلم & 1 & Dاه & ( & FF fF & 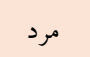 & كد v v v v \\
\hline زير دييلم & خانه دار & دييلم & آزاد & r & F/ه & ال & 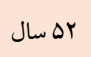 & 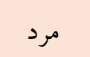 & كد 1 \\
\hline
\end{tabular}

$$
\text { () اولين مضمون: نغرانىها }
$$

يافته ها

اولين مضمون، نگر انى هاى ايجاد شده به دنبال بروز و شيوع ويروس كرونا

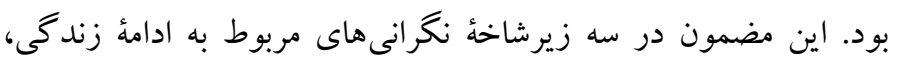

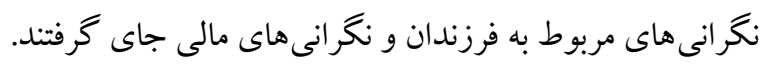

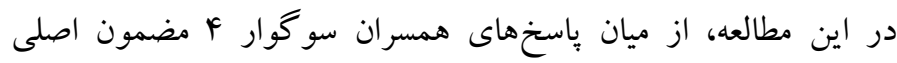

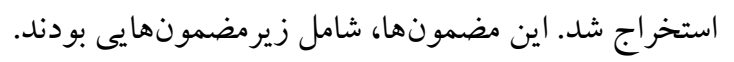


واكنشهاى رفتارى: همسران سو گوار، واكنشهايى مانند مقاومت براى

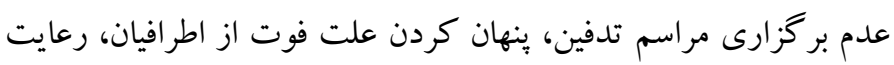

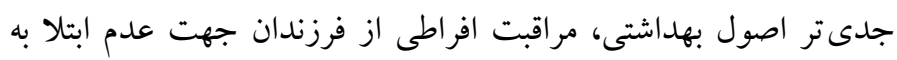

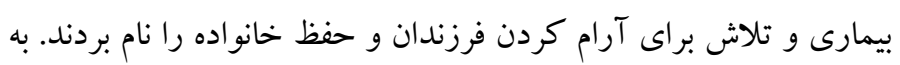
عنوان مثال؛ كد ب: خب من خودم خيلى اصرار كردم كه مراسمى نباشه،

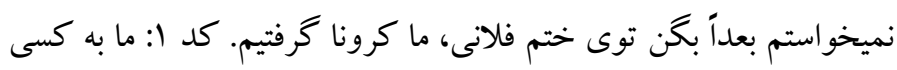

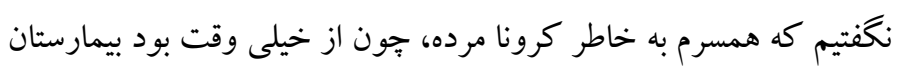
بسترى بود، ولى خب به خودمون كفتند همون توى بيمارستان كرونا گر فته

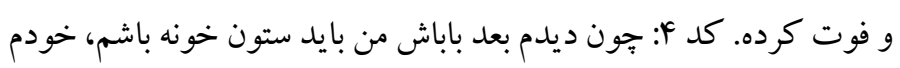
رو جلوى بجهه، محكم نخه داشتم.

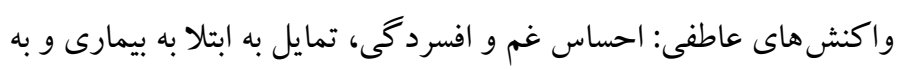

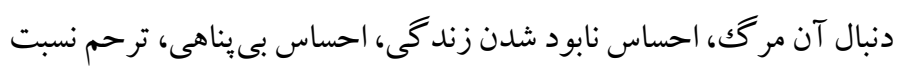
به همسر فوت شده، از جمله مفاهيمى بود كه در ميان صحبت هاى همسران

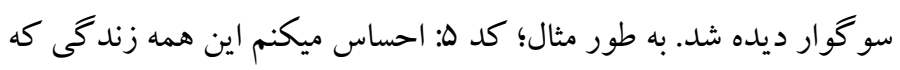

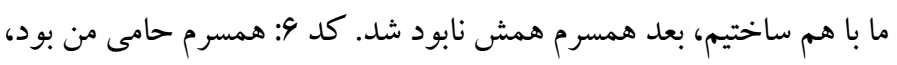

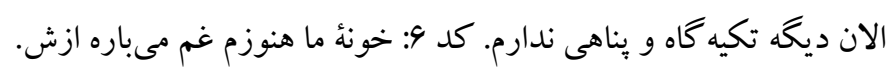

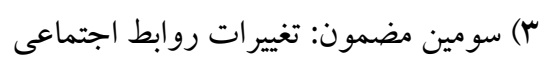

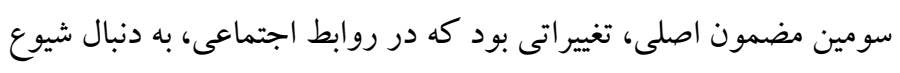

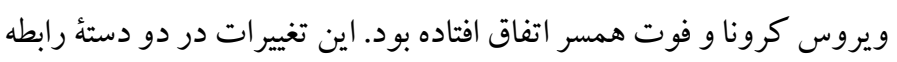
با اقوام و رابطه باهمكاران قرار گرفيتد.

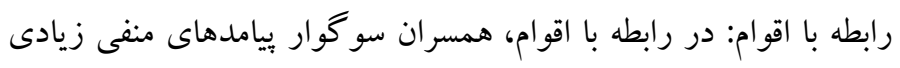

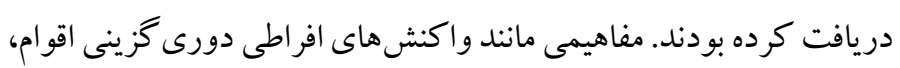
احساس طرد شدن، احساس انگك بيمارى و كاهش كيفيت روابط از

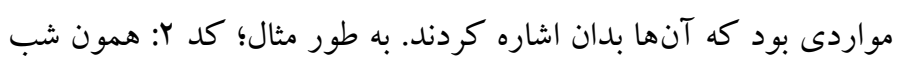
فوت همسرم من تنهاى تنها بودم، هيج كس بيشم نموند، همه ترسيدند و ازم

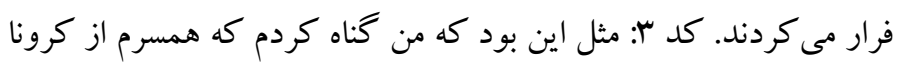

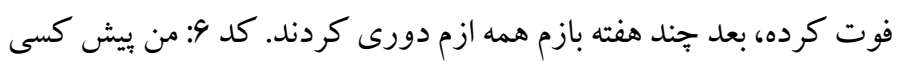

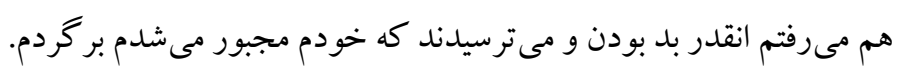

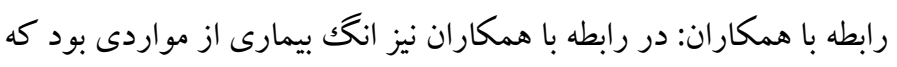

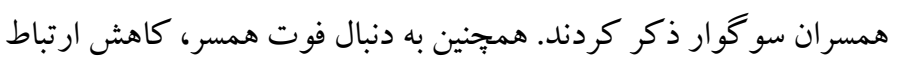

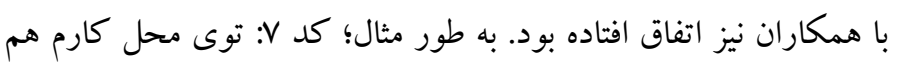

نخرانى هاى مربوط به ادامهٔ زندگى: اغلب همسر ان سو گوار در اين بثوهش

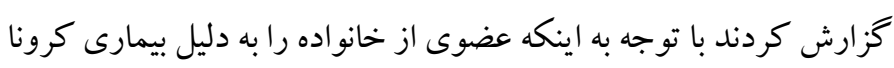

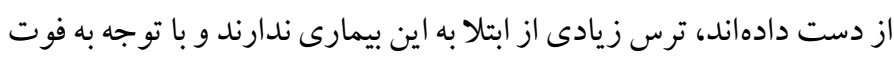

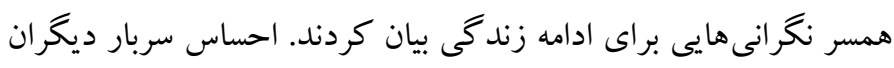

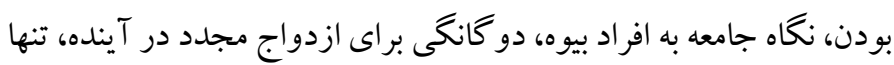

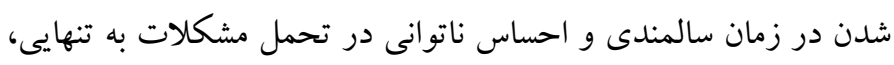
مفاهيمى بود كه از صحبت هاى اين گروه همسران استخراج شد. به طور

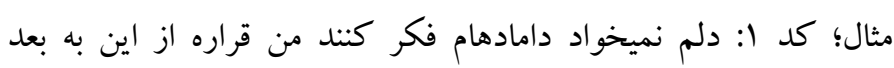

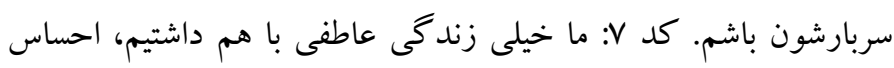

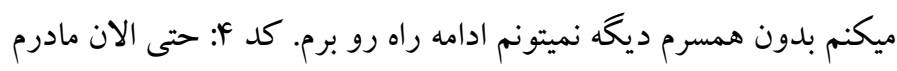
ميگه تو مىتونى ازدواج كنى.

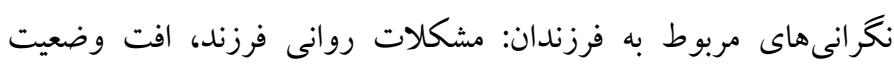

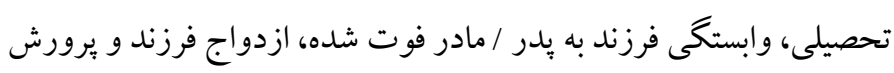

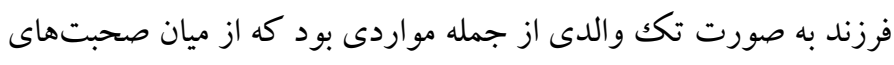

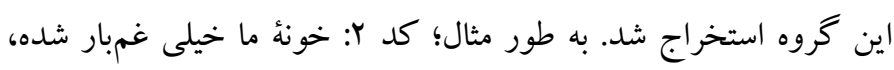

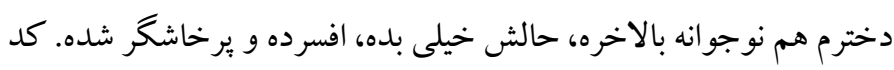

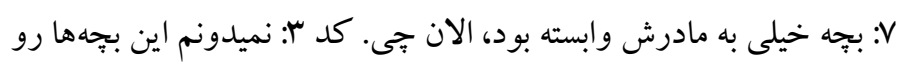
جطورى توى اين اوضاع تنهايى بزر گشون كنم.

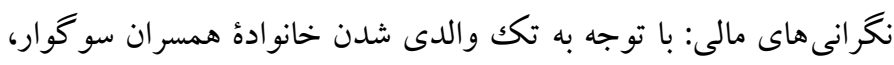

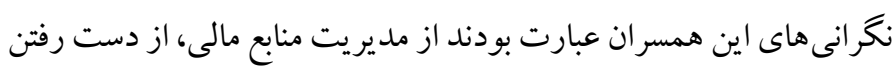

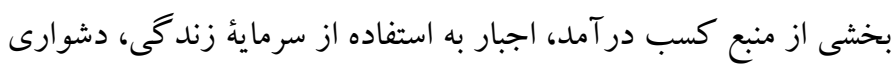

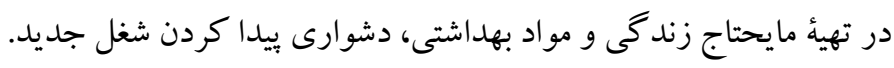

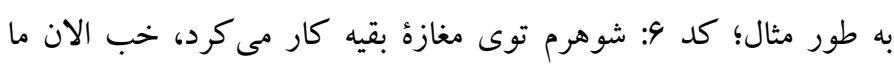

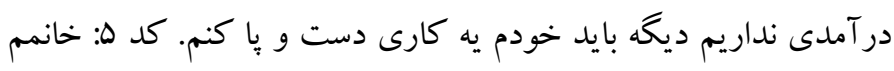

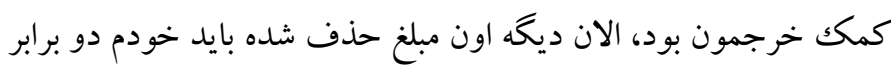

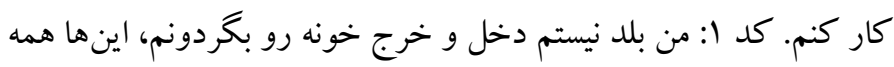

$$
\text { دست همسرم بود. }
$$

r) دومين مضمون: واكنش هاى شخصى دومين مضمون، واكنشهاى شخصى افراد در زمان بروز و شيوع ودئ ويروس

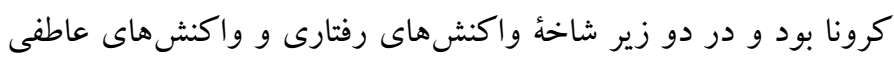

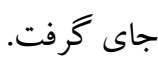


كه شامل فرزندان، در آمد، صميميت و هويت مشتركك بوده است (هاسه و

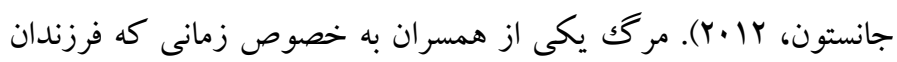

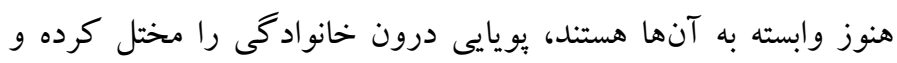

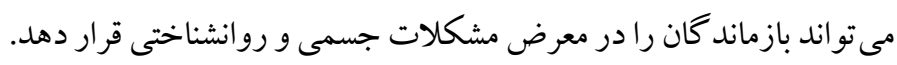

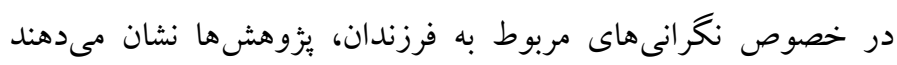

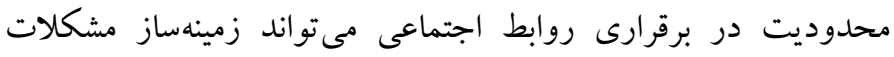

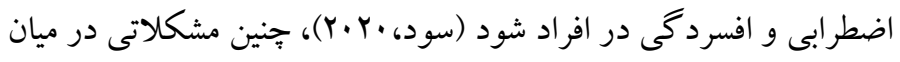

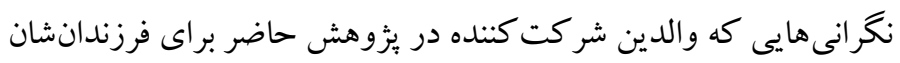

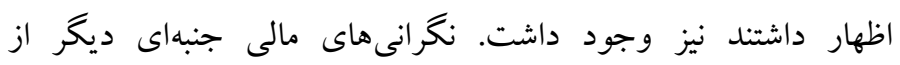

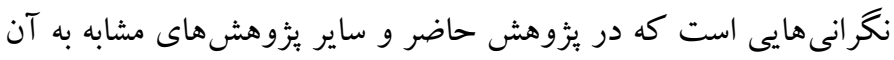
اشاره شده است؛ كوويد-19 باعث شده ضربؤ بزرگى به اقتصاد كشورها وارد شود و براى مردم، نامنى مالى و استرسهاى ناشى از آن را به دنبال

$$
\text { داشته است (موهانتى، •r.r. (r). }
$$

دومين مضمون يُزوهش، واكنش هاى شخصى بود كه همسران سو گو ار، هر

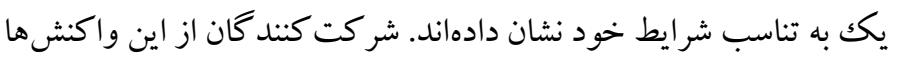

با عنو ان واكنش هاى جسمى و واكنش هاى عاطفى ياد كردند.

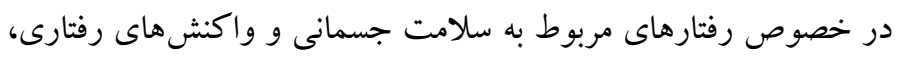

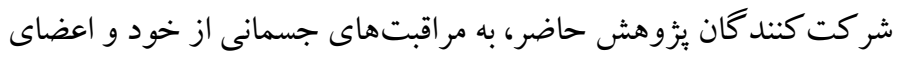

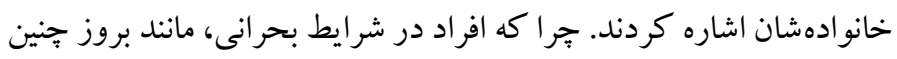
بيمارى هايى، به شدت نكران وضعيت خانو اده خود شده و به دنبال مراقبت

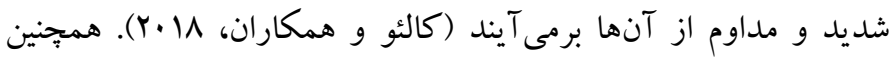
همسران سو گوار، افزون بر تلاشهايى كه جهت حفظ سلامت ساير اعضاى خانواده داشتند، در خصوص سلامتى همسر از دست رفته نيز رفتارهايى نظير ينهان كارى از خود نشان داده بودند. سومين مضمون، مربوط به تغييراتى است كه در روابط اجتماعى

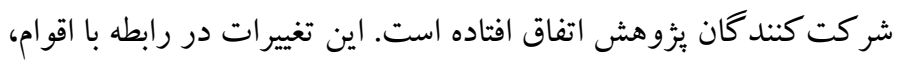

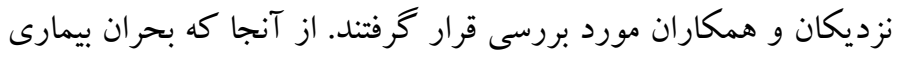
كرونا، افراد را در مهمترين، متعهدترين و صميمى ترين روابطشان تحت فت فرد

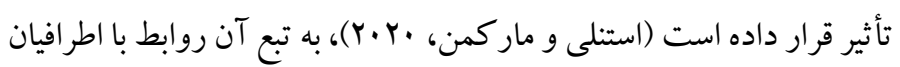
مانند اقوام و همكاران نيز تحت تأثير قرار مى گيرد. آخرين مضمون استخر اج شده، تغيير ديد گاهى بود كه همسر ان سو گوار به ديه آن اشاره كردند. تغيير ديدكاه نسبت به دنيا و نسبت به اطرافيان از ميان
هيج كس نزديكم نميومد. كد ا: يكك بخش از آدمهايى كه ما به عنوان مثلاً

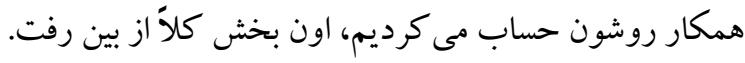
F) جهارمين مضمون اصلى: تغيير ديد گاه

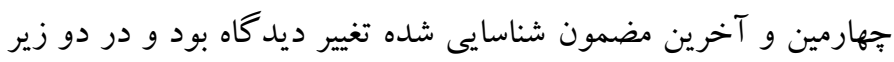

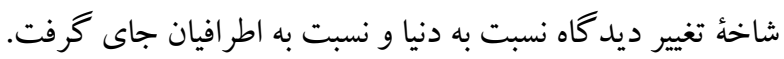

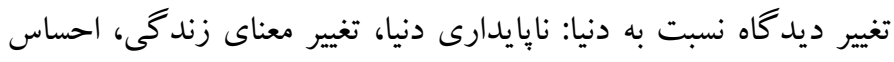

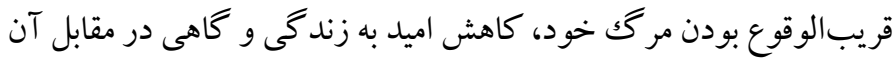

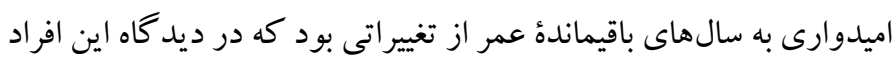

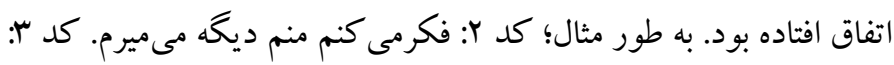

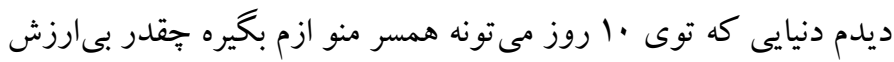

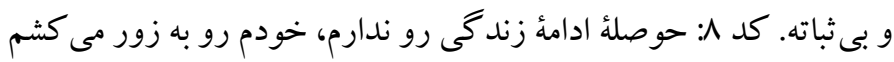
تا وقتى بميرم. كد ا: من به بهتر شدن وضع خودم و وضع دنيا اميدوارم. تغيير ديدگاه نسبت به اطرافيان: شناخت بيشتر اقوام و نزديكان، شناخت

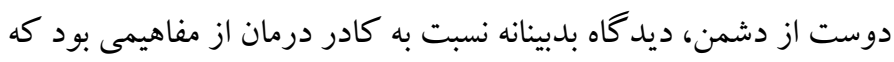

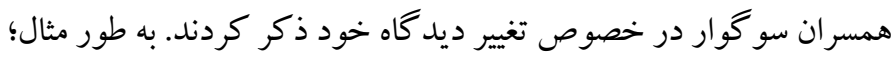

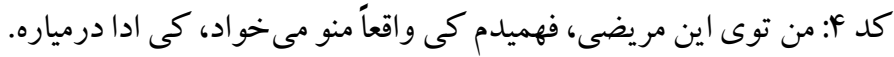

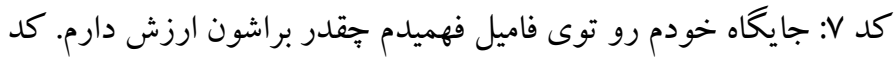

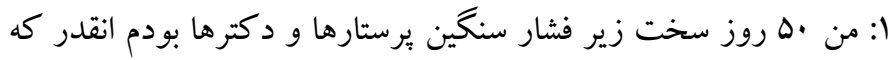
روحئه منو از بين بردند و بدرفتارى كردند.

بحث و نتيجه Fيرى هدف از يزوهش حاضر شناسايى عميق تجارب زيسته همسران سو گوارى

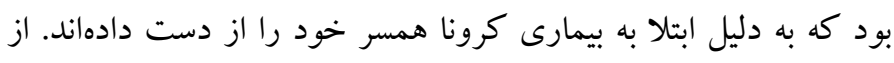

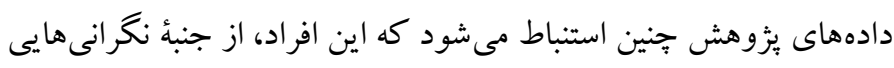

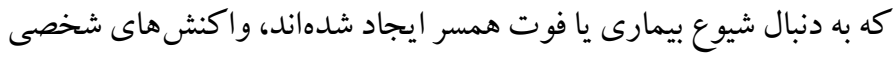
خودشان، تغييرات روابط اجتماعى و تغيير ديدگاههايشان، تحت تأثير قرار مى گيرند. اولين مضمون استخر اج شده، نخرانىهاى اين گروه از همسران بود، كه در

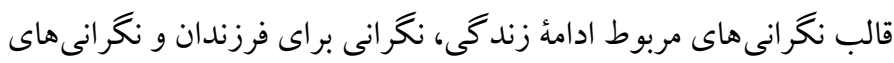

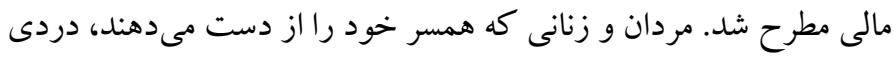

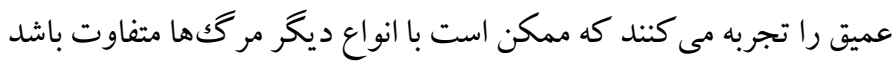

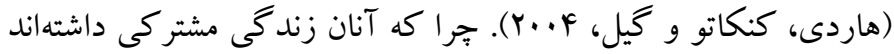


تعداد نمونهُ مورد مطالعه، بايد در تعميم نتايج احتياط كرد. بيشنهاد مىشود تجارب زيسته فرزندان و والدين نيز مورد مطالعه قرار كيرد. در اين صورت

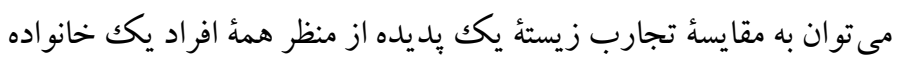
يرداخت. نتايج يزوهش حاضر مىتواند براى طراحى بستهاى آموزشى توانمندسازى همسران سو گوار از بيمارى كرونا مفيد واقع شود و مورد

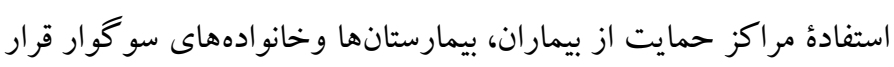
كيرد. همجزين مى تواند براى مطالعات فرهنگى كه به بررسى اين بيمارى و تأثيرات آن در ميان فرهنگ كشورهاى مختلف مى يردازند، مورد استفاده قرار كيرد.

\section{ملاحضات اخلاقى}

ييروى از اصول اخلاق يخوهش: قبل از شركت در يثزوهش به تمام شركت كنند كان

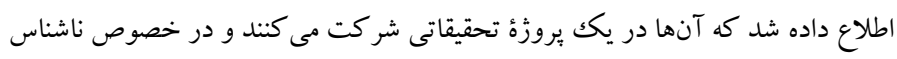

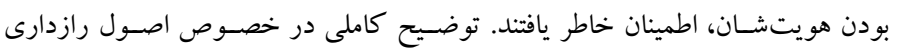

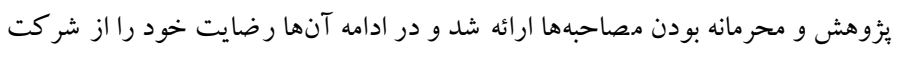

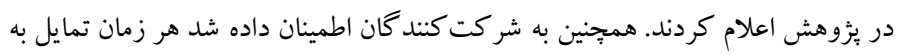

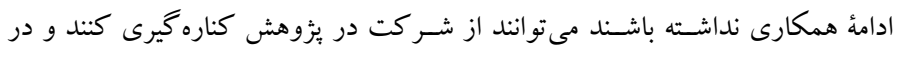

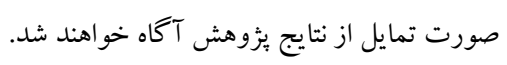
حامى مالى: مطالعه حاضر بدون حمايت مالى نهاد يا موسسه خاصى انجام شده است. نقش هر يكك از نوي سند كان: دكتر حسين يورشهريار: آماده كردن بخش مقدمه و روش مقاله، ثمين بهارشـانجانى: انجام مصـاحبههاى كيفى و آماده كردن بخش بحث و و

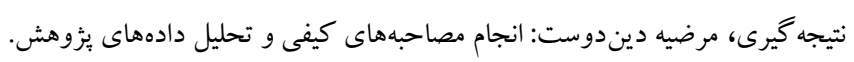
تضاد منافع: در يثزوهش حاضر ميان نويسند كان تعارض منافعى وجود ندارد.

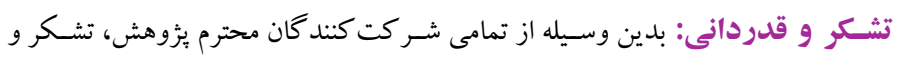
قدردانى مىشود.
اظهارات افراد استنباط و استخراج شد. بيمارى كرونا اگرجهه به سلامتى و رفاه افراد آسيب رسانده، به اقتصادهاى كشورهاى مختلف صدمه وارد كرده و منجر به بى اطمينانى نسبت به آينده شده است، اما ممكن است نتايج مثبى نيز در انكيزه افراد براى محافظت از روابطشان ايجاد كرده باشد

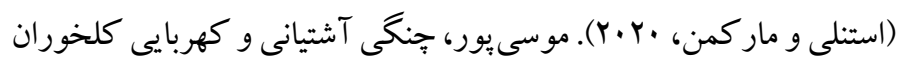
عليا (9هM) نيز بيان كردند همه گيرى اين بيمارى، با وجود همهٔ رنج و دردهايى كه به همراه داشته است، انسان را واداشته تا در مورد معناى وجودى و مفاهيم مرتبط به آن مانند مرگك، بيشتر از قبل بينديشد و اين انديشيدنها منجر به شكل گيرى باورهاى رشديافته براى او خو اهد شده. در همسر ان سو گوار تغيير ديد گاه در رابطه با اطرافيان نيز اتفاق افتاده بود. با توجه به آنكه در دوران شيوع يكك بيمارى، آسيب يذيرى خانو ادهها بيشتر

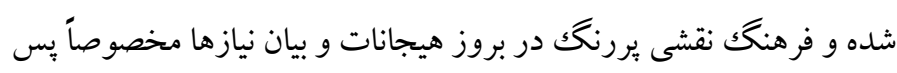

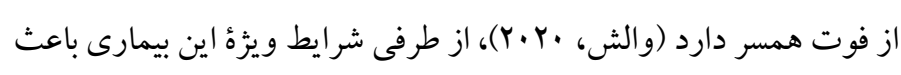
تأكيد زياد بر حفظ فاصلهُ فيزيكى و اجتماعى بين افراد شده است، مجموعة

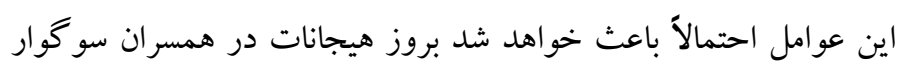
كمتر شود و به دنبال بر آورده نشدن اين نيازهايشان، ديد كاهشان به اطر افيان تغيير اتى داشته است. آنجه اهميت دارد اين است كه همسران سو گوار در اين دوره نياز به حمايت دارند، و اكر به صورت فيزيكى و حضورى نمى توان جنين حمايتهايى را براى آنها فراهم كرد، لازم است به طرق ديخرى اين مهم انجام شود. از جمله محدوديتهاى يزٔوهش مى توان به اين مسئله اشاره كرد كه با توجه به موقعيت مكانى يزوهشكران و افراد مورد مطالعه و با توجه به شيوع ويروس كرونا، مصاحبه ها تلفنى انجام كرفته است و اين امر ممكن است باعث از دست رفتن بخشى از دادههاى غير كلامى شود. همجِنين با توجه به 


\section{References}

Bai, Y., Yao, L., Wei, T., Tian, F., Jin, D.-Y., Chen, L., \& Wang, M. (2020). Presumed asymptomatic carrier transmission of COVID-19. Jama, 323(14), 14061407. [link]

Brooks, S. K., Webster, R. K., Smith, L. E., Woodland, L., Wessely, S., Greenberg, N., \& Rubin, G. J. (2020). The psychological impact of quarantine and how to reduce it: rapid review of the evidence. The lancet, 395(10227), 912-920. [link]

Reynolds, D. L., Garay, J., Deamond, S., Moran, M. K., Gold, W., \& Styra, R. (2008). Understanding, compliance and psychological impact of the SARS quarantine experience. Epidemiology \& Infection, 136(7), 997-1007. [link]

Barbisch, D., Koenig, K. L., \& Shih, F.-Y. (2015). Is there a case for quarantine? Perspectives from SARS to Ebola. Disaster medicine and public health preparedness, 9(5), 547-553. [link]

Desclaux, A., Badji, D., Ndione, A. G., \& Sow, K. (2017). Accepted monitoring or endured quarantine? Ebola contacts' perceptions in Senegal. Social science \& medicine, 178, 38-45. [link]

Cava, M. A., Fay, K. E., Beanlands, H. J., McCay, E. A., $\&$ Wignall, R. (2005). The experience of quarantine for individuals affected by SARS in Toronto. Public Health Nursing, 22(5), 398-406. [link]

Duan, L., \& Zhu, G. (2020). Psychological interventions for people affected by the COVID-19 epidemic. The lancet psychiatry, 7(4), 300-302. [link]

Rubin, G. J., \& Wessely, S. (2020). The psychological effects of quarantining a city. Bmj, 368. [link]

Ayittey, F. K., Ayittey, M. K., Chiwero, N. B., Kamasah, J. S., \& Dzuvor, C. (2020). Economic impacts of Wuhan 2019-nCoV on China and the world. Journal of medical virology, 92(5), 473. [link]

American Psychological Association. (2020). COVID-19 isn't just a danger to older people's physical health. [link]

Barton, A. W., Beach, S. R., Bryant, C. M., Lavner, J. A., \& Brody, G. H. (2018). Stress spillover, African Americans' couple and health outcomes, and the stress-buffering effect of family-centered prevention. Journal of Family Psychology, 32(2), 186. [link]

Kristensen, P., Weisæth, L., \& Heir, T. (2012). Bereavement and mental health after sudden and violent losses: A review. Psychiatry: Interpersonal \& Biological Processes, 75(1), 76-97. [link]
Li, X., Aida, J., Hikichi, H., Kondo, K., \& Kawachi, I. (2019). Association of postdisaster depression and posttraumatic stress disorder with mortality among older disaster survivors of the 2011 Great East Japan Earthquake and Tsunami. JAMA network open, 2(12), e1917550-e1917550. [link]

Gamino, L. A., Easterling, L. W., Stirman, L. S., \& Sewell, K. W. (2000). Grief adjustment as influenced by funeral participation and occurrence of adverse funeral events. OMEGA-Journal of Death and Dying, 41(2), 79-92. [link]

Hardy, S. E., Concato, J., \& Gill, T. M. (2004). Resilience of community-dwelling older persons. Journal of the American Geriatrics society, 52(2), 257-262. [link]

Haase, T. J., \& Johnston, N. (2012). Making meaning out of loss: A story and study of young widowhood. Journal of Creativity in Mental Health, 7(3), 204221. [link]

Sood, S. (2020). Psychological effects of the Coronavirus disease-2019 pandemic. Research \& Humanities in Medical Education, 7(11), 23-26. [link]

Mohanty, P. (2020). Coronavirus Lockdown I: Who and how many are vulnerable to COVID-19 pandemic. Business today [Internet]. [link]

Caleo, G., Duncombe, J., Jephcott, F., Lokuge, K., Mills, C., Looijen, E.,... Squire, J. (2018). The factors affecting household transmission dynamics and community compliance with Ebola control measures: a mixed-methods study in a rural village in Sierra Leone. BMC public health, 18(1), 1-13. [link]

Stanley, S. M., \& Markman, H. J. (2020). Helping couples in the shadow of COVID-19. Family process, 59(3), 937-955. [link]

Musapur, H., Changi ashtiyani, j., \& Kahrobaei kalkhuran alya, M. (2020). Spiritual and Existential Growth and COVID 19 pandemic: A qualitative study. Research in Psychological Health, 14(1), 56-70. [link]

Walsh, F. (2020). Loss and resilience in the time of COVID-19: Meaning making, hope, and transcendence. Family process, 59(3), 898-911. [link] 